\title{
IMPROVING STUDENTS' CRITICAL THINKING ABILITY AND RESILIENCY USING PROBLEM-SOLVING APPROACH
}

\author{
Rizky Laili Maulani ${ }^{1}$, H.E.T Ruseffendi ${ }^{2}$, Kustiana ${ }^{3}$ \\ ${ }^{1}$ IKIP Siliwangi Bandung \\ Kisay2993@gmail.com \\ 2 IKIP Siliwangi Bandung \\ ${ }^{3}$ IKIP Siliwangi Bandung
}

\begin{tabular}{l|l} 
Penerimaan : 16 Oktober 2018 & Diterima: 5 Juni 2019
\end{tabular}

\begin{abstract}
ABSTRAK
Latar belakang penelitian ini adalah rendahnya kemampuan penalaran, berpikir kritis, dan resiliansi matematik siswa SMPN di Kota Cimahi. Tujuan dari penelitian ini adalah untuk menganalisis peran pendekatan problem solving terhadap kemampuan berpikir kritis dan resiliansi matematik. Penelitian ini merupakan penelitian eksperimen dengan desain pretes postes kontrol grup dan melibatkan 65 siswa kelas delapan dari SMPN 8 Cimahi yang dipilih secara acak sekolah dan kelas. Instrumen yang digunakan dalam penelitian ini adalah tes kemampuan berpikir kritis matematik, serta skala resiliansi matematik. Penelitian ini menemukan bahwa peningkatan kemampuan berpikir kritis matematik siswa yang mendapatkan pembelajaran dengan pendekatan problem solving tidak lebih baik atau sama dengan siswa yang diajarkan dengan pembelajaran konvensional, sedangkan resiliansi matematik siswa yang mendapatkan pembelajaran dengan pendekatan problem solving tidak lebih baik atau sama dengan siswa yang diajarkan dengan pembelajaran konvensional. Selain itu, tidak ada asosiasi antara kemampuan berpikir kritis dengan resiliansi matematik. Temuan lainnya bahwa siswa masih kesulitan dalam menyelesaikan soal kemampuan berpikir kritis matematik.
\end{abstract}

Kata Kunci : berpikir kritis matematik, resiliansi, pendekatan problem solving

\section{ABSTRACT}

The background of this research is the low ability of reasoning, critical thinking, and mathematical resilience of SMPN students in Cimahi City. The purpose of this research is to analyze the role of problem-solving approach to critical thinking ability and mathematical resilience. This study was an experimental study with a pretest post control group design and involved 65 eighth grade students from SMPN 8 Cimahi who were randomly selected for school and class. The instrument used in this research is the test of critical mathematical thinking ability, as well as the scale of mathematical resilience. This study found that the improvement of critical thinking ability of mathematics students who get learning with the problem-solving approach is not better or equal to students taught by conventional learning, while the mathematical resilience of students who get learning with the problem-solving approach is not better or equal to students who are taught with conventional learning. In addition, there is no association between critical thinking ability and mathematical resilience. Another finding that students are still difficult in solving the problem of critical mathematical thinking skills.

Keywords: critical mathematical thinking, resilience, problem-solving approach 


\section{PENDAHULUAN}

Penyelenggaraan matematika sekolah di Indonesia saat ini diatur dalam kurikulum yang mengacu pada prinsip belajar sepanjang hayat, prinsip siswa belajar aktif, prinsip learning how to learn yang rinciannya termuat dalam empat pilar pendidikan UNESCO, serta memuat kompetensi dan sikap yang harus dimiliki siswa setelah mereka belajar. Prinsip-prinsip tersebut bertujuan untuk mencapai visi matematika. Visi pertama mengarahkan pembelajaran matematika untuk pemahaman konsep dan ide matematika dalam menyelesaikan permasalahan matematika dan bidang ilmu lainnya. Visi kedua melalui pembelajaran matematika dapat mengembangkan kemampuan menalar yang logis, sistematis, kritis dan cermat, menumbuhkan rasa percaya diri, sadar akan indahnya sistematika sifat matematika, dan mampu bersikap obyektif yang diperlukan pada era globalisasi.

Selain itu, hasil pendidikan matematika yang diajarkan disekolah dapat membantu mewujudkan prioritas utama dari sebuah sistem pendidikan. Sebagaimana dikemukakan Ruseffendi (1991:283), "Hasil dari pendidikan matematika yaitu siswa diharapkan memiliki kepribadian yang kreatif, kritis, berpikir ilmiah, jujur, hemat, disiplin, tekun, berprikemanusiaan, mempunyai perasaan keadilan dan bertanggung jawab terhadap kesejahteraan bangsa dan negara".

Menurut Scriven (Hadinata, 2009:10), 'Berpikir kritis adalah interpretasi dan evaluasi yang terampil dan aktif terhadap observasi dan komunikasi, informasi dan argumentasi'. Kemampuan berpikir kritis sangat diperlukan dalam kehidupan sehari-hari karena dalam kehidupan sehari-hari terdapat banyak masalah dan hambatan yang memerlukan pemecahan masalah atau solusi yang menuntut seseorang memiliki kemampuan berpikir kritis. Hal ini didukung oleh pendapat Ennis (Susilawati, 2014:202) yaitu, 'Berpikir kritis adalah suatu proses dengan tujuan membuat keputusan yang masuk akal tentang apa yang diyakini atau dilakukan'. Oleh karena itu, seseorang yang memiliki kemampuan berpikir kritis dapat mengambil sebuah keputusan dalam bertindak secara cepat dan tepat.

Selain kemampuan berpikir kritis matematik yang harus dikembangkan dalam pembelajaran matematika, resiliansi matematik juga perlu untuk dikembangkan dalam pembelajaran matematika. Hal ini dikarenakan masih banyak siswa yang mengalami 
kesulitan dan ketidaksukaan dalam belajar matematika. Kesulitan dan ketidaksukaan dalam belajar matematika ditunjukkan dengan rasa cemas, takut, dan kesulitan dalam memecahkan masalah.

Siswa dengan resiliansi yang baik, sadar bahwa andai mereka berpikir keras, berdiskusi dengan teman-temannya, membaca ide-ide matematik, merefleksikan pengetahuan yang diperolehnya, maka mereka akan tangguh dan dapat mengatasi tantangan dalam belajar matematik serta mampu menyelesaikan masalah matematik yang sulit. Selain itu, menurut Johnston-Wilder dan Lee (2010) menyatakan bahwa siswa yang memiliki ketahanan matematika akan bertahan ketika menghadapi kesulitan, bekerja secara kolaboratif dengan teman-teman mereka, memiliki keterampilan bahasa yang diperlukan untuk mengekspresikan pemahaman mereka dan memiliki teori pembelajaran berkembang, yaitu mereka akan tahu bahwa semakin banyak mereka mempelajari matematika semakin sukses penapaian mereka terhadap pembelajaran matematika.

Realita yang terjadi di lapangan siswa lebih terfokus pada jawaban sehingga siswa sering kali salah dalam menentukan teknik penyelesaian yang sesuai dengan permasalahan. Sejalan dengan pendapat tersebut Takwin (Rohaeti, 2008:10) menyatakan, "Siswa merasa dituntut untuk memecahkan masalah secepat mungkin dan tidak berusaha untuk memahami terlebih dahulu masalah tersebut". Selain itu, berdasarkan hasil penelitian TIMSS (Trends in Mathematics and Science Study) pada tahun 2011 dengan populasi siswa kelas VIII, pada bidang matematika berada pada peringkat 38. Hal ini terlihat pada rata-rata skor yang diperoleh adalah 386 sedangkan skala skor tengah yang ditetapkan oleh TIMSS adalah 500. Berdasarkan hasil tersebut, dapat disimpulkan bahwa aspek kognitif siswa SMP di Indonesia masih rendah dalam hal ini aspek pengetahuan, penerapan dan penalaran. Selain itu, penelitian yang dilakukan oleh Rohaeti (2010) dengan subjek siswa SMP mengemukakan bahwa presentase kemampuan berpikir kritis matematik siswa sebanyak $57,26 \%$ tergolong rendah dan $40,60 \%$ berada di tergolong sedang.

Selain itu, matematika dianggap oleh siswa sebagai salah satu mata pelajaran sekolah yang paling rumit dan bermasalah. Siswa menghadapi kesulitan dalam matematika karena beberapa alasan diantaranya dalam konsep yang berbeda dan banyaknya strategi pemecahan masalah. Hal ini sejalan dengan pendapat Johnston-Wilder dan Lee (2010) yang menyatakan bahwa banyak orang merasa sulit untuk mengambil bagian dalam pembelajaran matematika, mereka menunjukkan kecemasan atau menghindar dalam 
keterlibatan aktivitas apa pun yang membutuhkan penalaran matematik, dan banyak orang mendekati matematika dengan beberapa tingkat ketakutan.

Berdasarkan hasil dari penelitian yang dikemukakan oleh Widyatiningtyas, Kusumah, Sumarmo, dan Sabandar (2015:32) menyimpulkan bahwa hasil pembelajaran dengan menggunakan pendekatan konvensional yang lebih berpusat pada guru menyebabkan siswa pasif dan guru menjadi satu-satunya sumber informasi sehingga pembelajaran matematika yang diterapkan tidak dapat melatih kemampuan berpikir tinggi yang dimiliki oleh siswa tersebut. Untuk mengatasi permasalahan tersebut, guru dapat mengupayakan metode pendekatan dan model pembelajaran yang dapat melatih kemampuan matematik serta sikap positif terhadap pembelajaran matematik. Salah satu metode pendekatan yang dapat diterapkan dalam mengantisipasi masalah dan dapat melatih kemampuan penalaran, berpikir kritis, dan meningkatkan resiliansi matematik siswa selama proses belajar dan mengajar adalah pendekatan problem solving.

Menurut Majid (2013:212), "Metode problem solving merupakan pembelajaran berbasis masalah, yakni pembelajaran yang berorientasi pada pemecahan suatu masalah oleh siswa melalui kerja kelompok". Pendekatan problem solving merupakan salah satu metode pembelajaran yang menuntut siswa untuk melakukan aktivitas pemecahan masalah yang dimulai dengan mencari berbagai informasi, menganalisis dan mencari solusi dari permasalahan yang ada. Adapun langkah-langkah pendekatan problem solving adalah memahami masalah melalui identifikasi masalah, menyusun rencana dengan menentukan aturan umum dan mencari strategi penyelesaian, melaksanakan rencana penyelesaian, dan memeriksa hasil dan proses dengan mencari cara lain untuk menyelesaikan masalah.

Untuk mengamati karakteristik pendekatan problem solving, berpikir kritis dan resiliansi matematik, dan beberapa temuan mengenai pendekatan problem solving terhadap peningkatan berpikir kritis dan resiliansi matematik, maka penelitian ini bertujuan untuk:

a. Menganalisis peran pendekatan problem solving dalam meningkatkan berpikir kritis dan resiliansi matematik siswa;

b. Menganalisis kesulitan siswa dalam memecahkan berpikir kritis matematik;

c. Menganalisis hubungan antara berpikir kritis dengan resiliensi matematik. 


\section{METODOLOGI PENELITIAN}

Metode yang digunakan dalam penelitian adalah eksperimen dengan melibatkan dua kelompok, yaitu kelas eksperimen dan kelas kontrol yang pengambilan sampelnya dengan cara acak kelas. Maka menurut metodenya, penelitian ini adalah penelitian eksperimen dengan disain kelompok kontrol pretes-postes (pretest-posttest-control group design), yaitu desain kelompok yang melibatkan dua kelompok dengan pengambilan sampel dilakukan secara acak kelas. Menurut Ruseffendi (2010:50) bagan desain kelompok kontrol pretes-postes (pretest-posttest-control group design) adalah,

$\begin{array}{llll}\text { A } & \mathrm{O} & \mathrm{X} & \mathrm{O} \\ \mathrm{A} & \mathrm{O} & & \mathrm{O}\end{array}$

Keterangan:

A : pengambilan sampel secara acak kelas;

$\mathrm{O} \quad$ : soal pretes $=$ soal postes kemampuan berpikir kritis matematik;

$\mathrm{X} \quad$ : pengajaran matematika dengan pendekatan problem solving.

Populasi dalam penelitian ini adalah seluruh SMPN di Kota Cimahi, dari 11 sekolah dipilih secara acak dan sekolah yang terpilih adalah SMPN 8 Cimahi. Sampel dalam penelitian ini adalah kelas VIII. Berdasarkan teknik pengambilan sampel tersebut diambil dua sampel dari kelas VIII yang dipilih secara acak kelas. Kelas yang terpilih yaitu kelas VIII B sebagai kelas eksperimen dan kelas VIII A sebagai kelas kontrol. Kelas eksperimen diberikan pembelajaran dengan menggunakan pendekatan problem solving dan kelas kontrol diberikan pembelajaran biasa.

Penelitian ini melibatkan dua instrumen yaitu tes kemampuan berpikir kritis matematik dan skala resiliensi. Tes kemampuan berpikir kritis matematik terdiri dari 5 item yang karakteristiknya sebagai berikut: validitas isi, validitas item; uji reliabilitas, Daya Pembeda dan Indeks Kesulitan. Sedangkan instrumen non tes dalam penelitian ini adalah skala kuesioner / sikap untuk mengukur resiliensi matematik. Kuesioner disusun sebanyak 40 pernyataan yang terdiri dari 20 pernyataan positif dan 20 pernyataan negative.

\section{HASIL DAN PEMBAHASAN}

Rekapitulasi data deskriptif hasil penelitian secara keseluruhan dapat dilihat pada tabel berikut: 
Tabel 1. Rekapitulasi Deskripsi Data Hasil Penelitian Kemampuan Berpikir Kritis dan Resiliensi Matematika Siswa

\begin{tabular}{|c|c|c|c|c|c|c|c|c|c|}
\hline \multirow[t]{2}{*}{ Kemampuan } & \multirow[t]{2}{*}{ Stat } & \multicolumn{4}{|c|}{ Pendekatan Problem Solving } & \multicolumn{4}{|c|}{ Pembelajaran Biasa } \\
\hline & & Pretest & Postest & N-Gain & $\mathbf{N}$ & Pretest & Postest & N-Gain & $\mathbf{N}$ \\
\hline \multirow{3}{*}{$\begin{array}{l}\text { Berpikir Kritis } \\
\text { SMI = } 48\end{array}$} & $\bar{x}$ & 8,70 & 27,36 & 0,48 & \multirow[t]{6}{*}{33} & 4,31 & 26,25 & 0,51 & \multirow[t]{6}{*}{32} \\
\hline & $\%$ & $13,59 \%$ & $42,76 \%$ & $47,60 \%$ & & $6,74 \%$ & $41,02 \%$ & $50,91 \%$ & \\
\hline & $\mathrm{Sd}$ & 0,77 & 8,25 & 0,21 & & 2,60 & 8,20 & 0,17 & \\
\hline \multirow{3}{*}{$\begin{array}{c}\text { Resiliansi SMI }= \\
160\end{array}$} & $\bar{x}$ & \multicolumn{3}{|c|}{104.24} & & \multicolumn{3}{|c|}{103.56} & \\
\hline & $\%$ & \multicolumn{3}{|c|}{$65.15 \%$} & & \multicolumn{3}{|c|}{$64.73 \%$} & \\
\hline & $\mathrm{Sd}$ & \multicolumn{3}{|c|}{14.03} & & \multicolumn{3}{|c|}{11.81} & \\
\hline
\end{tabular}

Berdasarkan Tabel 1 di atas menunjukkan bahwa rata-rata kemampuan awal berpikir kritis matematik siswa kelas eksperimen adalah 8,70 dan kelas kontrol adalah 4,31. Sedangkan persentase kemampuan awal berpikir kritis matematik siswa kelas eksperimen adalah 13,59\% dan kelas kontrol adalah 6,74\%. Terlihat secara umum bahwa terdapat perbedaan rata-rata skor persentase kemampuan awal antara siswa kelas eksperimen dengan kelas kontrol. Sedangkan, rata-rata peningkatan kemampuan berpikir kritis matematik siswa kelas eksperimen adalah 0,48 dan kelas kontrol adalah 0,51. Selain itu, rata-rata kemampuan berpikir kritis matematik siswa setelah diberikan perlakuan baik di kelas eksperimen adalah 27,36 dan kelas kontrol adalah 26,25. Sedangkan persentase kemampuan berpikir kritis matematik siswa kelas eksperimen adalah 42,76\% dan kelas kontrol adalah $41,02 \%$. Terlihat secara umum bahwa perbedaan rata-rata skor persentase kemampuan berpikir kritis matematik siswa kelas kontrol tidak jauh berbeda dengan kelas eksperimen.

Sedangkan persentase peningkatan kemampuan penalaran matematik siswa kelas eksperimen adalah 47,60\% dan kelas kontrol adalah 50,91\%. Terlihat secara umum bahwa rata-rata skor persentase peningkatan kemampuan berpikir kritis matematik siswa kelas eksperimen dengan kelas kontrol yang tidak jauh berbeda. Untuk mengetahui apakah terdapat perbedaan yang signifikan atau tidak antara kelas eksperimen dan kelas kontrol dilakukan uji statistik.

Selain itu, berdasarkan Tabel 1. di atas menunjukkan bahwa rata-rata resiliansi matematik siswa kelas eksperimen adalah 104,24 dan kelas kontrol adalah 103,56. Sedangkan persentase resiliansi matematik siswa kelas eksperimen adalah $65,15 \%$ dan 
kelas kontrol adalah $64,73 \%$. Terlihat secara umum bahwa rata-rata skor resiliensi matematik siswa baik kelas eksperimen dan kelas kontrol tidak jauh berbeda.

Tabel 2. Pengujian Hipotesis Perbedaan Berarti Kemampuan Berpikir Kritis Matematik, dan Ketahanan Matematika pada Kedua Pendekatan Pengajaran

\begin{tabular}{|c|c|c|c|c|c|c|c|}
\hline Variabel & Pendekatan & $\bar{x}$ & SD & $\mathbf{N}$ & $\begin{array}{l}\text { Sig }(2- \\
\text { tailed }) \text {. }\end{array}$ & Sig(1-tailed). & Interpretation \\
\hline \multirow{2}{*}{ BKM } & PS & 27,36 & 8,25 & 33 & \multirow[t]{2}{*}{0,793} & \multirow[t]{2}{*}{$0,396>0,05$} & \multirow[t]{2}{*}{$\mathrm{BKM}_{\mathrm{PS}} \leq \mathrm{BKM}_{\mathrm{Konv}}$} \\
\hline & Konv & 26,25 & 8,20 & 32 & & & \\
\hline \multirow{2}{*}{$\begin{array}{c}\text { N-Gain } \\
\text { BKM }\end{array}$} & PS & 0,48 & 0,21 & 33 & \multirow[t]{2}{*}{0,415} & \multirow[t]{2}{*}{$0,275<0,05$} & $\mathrm{~N}$ Gain $\mathrm{BKM}_{\mathrm{PS}} \leq$ \\
\hline & Konv & 0,51 & 0,17 & 32 & & & N-Gain BKM $\mathrm{Konv}_{\mathrm{K}}$ \\
\hline \multirow[b]{2}{*}{$\mathrm{RM}$} & PS & 104,24 & 14,03 & 33 & \multirow[t]{2}{*}{0,834} & \multirow[t]{2}{*}{$0,417<0,05$} & $\mathrm{RM}_{\mathrm{PS}}=\mathrm{RM}_{\mathrm{Konv}}$ \\
\hline & Konv & 103,56 & 11,81 & 32 & & & \\
\hline $\begin{array}{ll}\text { Note: } & \mathrm{B} \\
& \mathrm{R} \\
& \mathrm{P}\end{array}$ & $\begin{array}{l}\text { : Berpikil } \\
\text { : Resilian } \\
\text { : Problen }\end{array}$ & $\begin{array}{l}\text { Sritis M } \\
\text { Matem } \\
\text { Solving }\end{array}$ & $\begin{array}{l}\text { matik } \\
\mathrm{k}\end{array}$ & & & $\begin{array}{l}\text { l score } \\
\text { l score }\end{array}$ & $\begin{array}{l}60 \\
\text { onvensional }\end{array}$ \\
\hline
\end{tabular}

Temuan pada penelitian ini berbanding terbalik dengan hasil penelitian Perveen (2010), dan Karatas and Baki (2013) yang menyatakan bahwa pendekatan problem solving dapat meningkatkan prestasi dan kemampuan matematik yang lebih baik dibandingkan pembelajaran konvensional. Selain itu, temuan hubungan antara kemampuan berpikir kritis dan resiliansi matematik ditentukan dengan menggunakan Tabel Kontingensi seperti pada Tabel 3 dan Tabel 4.

Tabel 3. Jumlah Siswa Berdasarkan kriteria Tinggi, Sedang, Rendah Kemampuan Berpikir Kritis dan Resiliansi Matematik pada Kelas Problem Solving

\begin{tabular}{cccccc}
\hline \multirow{2}{*}{ Kemampuan } & \multicolumn{3}{c}{ Resiliansi Matematik } & \multirow{2}{*}{ Total } \\
\cline { 2 - 5 } & & Tinggi & Sedang & Rendah & \\
\hline \multirow{2}{*}{ Berpikir Kritis } & Tinggi & 2 & 6 & 1 & 9 \\
\cline { 2 - 5 } Matematik & Sedang & 1 & 2 & 0 & 3 \\
\cline { 2 - 5 } & Rendah & 8 & 5 & 8 & 21 \\
\hline Total & & 11 & 13 & 9 & 33 \\
\hline
\end{tabular}

Tabel 4. Hasil Uji Chi-Square antara Kemampuan Berpikir Kritis dengan Resiliansi Matematik

\begin{tabular}{lccr}
\hline & Value & $d f$ & $\begin{array}{c}\text { Asymptotic Significance } \\
\text { (2-sided) }\end{array}$ \\
\hline Pearson Chi-Square & $6,619^{\mathrm{a}}$ & 4 & 0,157 \\
\hline Likelihood Ratio & 7,448 & 4 & 0,114 \\
\hline $\begin{array}{l}\text { Linear-by-Linear } \\
\text { Association }\end{array}$ & 0,187 & 1 & 0,665 \\
\hline Nof Valid Cases & & & \\
\hline
\end{tabular}


Berdasarkan Tabel 4. dapat dilihat bahwa nilai signifikannya sebesar 0,157 yang berarti Asymptotic Sig (2-tailed) $>0,05$ maka $H_{0}$ diterima. Artinya, tidak terdapat asosiasi antara kemampuan berpikir kritis dengan resiliansi matematik di kelas yang pembelajarannya menggunakan pendekatan problem solving. Hal ini menunjukkan bahwa eksistensi asosiasi antara kemampuan berpikir kritis dengan resiliansi matematik tidak konsisten. Hal ini sejalan dengan hasil penelitian Murni (2017) yang menyatakan bahwa tidak terdapat asosiasi antara kemampuan berpikir kritis dan resiliansi matematik siswa SMA yang disebabkan resiliansi matematik korelasinya rendah dengan berpikir kritis matematik.

Temuan kesulitan siswa dalam menyelesaikan soal tes kemampuan berpikir kritis matematik dilampirkan pada Tabel 5.

\section{Tabel 5. Skor Rata-Rata Dari Setiap Soal dari Tes Berpikir Kritis Matematik Siswa Berdasarkan Pendekatan Pengajaran}

\begin{tabular}{|c|c|c|c|c|c|c|c|}
\hline \multirow[t]{2}{*}{ Kelas } & \multirow[t]{2}{*}{ Statistik } & \multicolumn{5}{|c|}{ No. Soal } & \multirow[t]{2}{*}{ Keseluruhan } \\
\hline & & 1 & 2 & 3 & 4 & 5 & \\
\hline \multirow[t]{5}{*}{ Eksperimen } & $\mathrm{N}$ & & & 33 & & & 33 \\
\hline & $X$ & 6,55 & 4,55 & 6,00 & 6,42 & 3,85 & 27,36 \\
\hline & $\mathrm{Sd}$ & 2,36 & 2,35 & 1,06 & 1,25 & 4,93 & 8,25 \\
\hline & SMI & 12 & 8 & 8 & 8 & 12 & 48 \\
\hline & $\%$ & $55 \%$ & $57 \%$ & $75 \%$ & $80 \%$ & $32 \%$ & $57,01 \%$ \\
\hline \multirow[t]{5}{*}{ Kontrol } & $\mathrm{N}$ & & & 32 & & & 32 \\
\hline & $\mathrm{X}$ & 6,63 & 3,63 & 5,63 & 6,06 & 4,31 & 26,25 \\
\hline & $\mathrm{Sd}$ & 3,68 & 1,48 & 2,06 & 1,19 & 4,25 & 8,20 \\
\hline & SMI & 12 & 8 & 8 & 8 & 12 & 48 \\
\hline & $\%$ & $55 \%$ & $45 \%$ & $70 \%$ & $76 \%$ & $36 \%$ & $54,69 \%$ \\
\hline \multirow[t]{5}{*}{ Keseluruhan } & $\mathrm{N}$ & & & 65 & & & 65 \\
\hline & $\mathrm{X}$ & 6,58 & 4,09 & 5,82 & 6,25 & 4,08 & 26,82 \\
\hline & $\mathrm{Sd}$ & 3,06 & 2,01 & 1,63 & 1,23 & 4,58 & 8,18 \\
\hline & SMI & 12 & 8 & 8 & 8 & 12 & 48 \\
\hline & $\%$ & $55 \%$ & $51 \%$ & $73 \%$ & $78 \%$ & $51 \%$ & $56 \%$ \\
\hline
\end{tabular}

Berdasarkan pada Tabel 5 dapat dilihat bahwa siswa kelas eksperimen maupun kontrol masih mengalami kesulitan dalam menyelesaikan soal berpikir kritis matematik dengan persentase pencapaian sebesar 56\% terhadap nilai ketuntasan 70 . Kelas eksperimen yang pembelajarannya menggunakan pendekatan problem solving mengalami kesulitan dalam menyelesaikan soal kemampuan berpikir kritis matematik dengan persentase 
keseluruhan sebesar 42,76\% terhadap nilai ketuntasan 70. Selain itu, berdasarkan Tabel 5. pada kelas kontrol yang pembelajarannya dengan menggunakan pembelajaran biasa tidak berbeda jauh dibandingkan dengan kelas eksperimen dalam menyelesaikan soal kemampuan penalaran matematik. Hal ini dapat dilihat dari persentase pencapaian keseluruhan sebesar 54,69\% terhadap terhadap nilai ketuntasan 70. Pada soal nomor 3 dan 4 siswa sudah mampu menyesaikan soal kemampuan berpikir kritis matematik baik pada kelas eksperimen maupun kelas kontrol. Sedangkan pada soal nomor 1, 2, dan 5 siswa baik kelas eksperimen maupun kelas kontrol masih mengalami kesulitan. Artinya siswa kelas eksperimen masih lemah dalam menyelesaikan soal kemampuan berpikir kritis dengan indikator menyusun jawaban/ menyelesaikan masalah matematika disertai alasan dan memeriksa kebenaran argumen, pernyataan dan proses solusi.
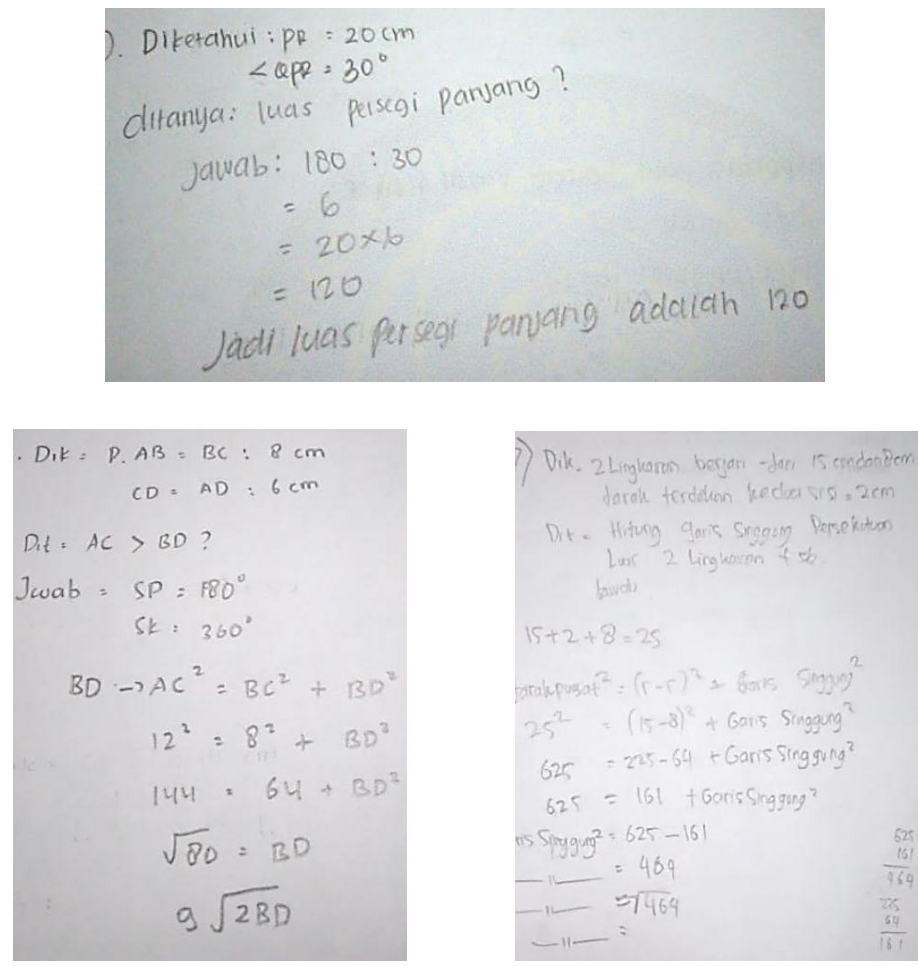

\section{Gambar 1. Sampel Pengerjaan Siswa Kelas Eksperimen dan Kontrol pada Soal Kemampuan Berpikir Kritis Matematik Nomor 1, 2, dan 5}

Berdasarkan pada Gambar 1 menunjukkan bahwa siswa kelas eksperimen maupun kontrol belum mampu menentukan cara penyelesaian masalah yang tepat dikarenakan siswa kelas kontrol belum memahami permasalahan dan belum menguasai materi atau konsep yang dipergunakan dalam penyelesaian masalah. Selain itu rata-rata siswa kelas kontrol belum mengidentifikasi langkah-langkah penyelesaian. Hal ini mengakibatkan siswa tidak dapat menempatkan informasi ke dalam langkah penyelesaian yang dipilih. 


\section{KESIMPULAN}

Berdasarkan hasil dan pembahasan penelitian dapat disimpulkan bahwa:

1. Peningkatan kemampuan berpikir kritis matematik siswa secara signifikan yang pembelajarannya menggunakan pendekatan problem solving tidak lebih baik atau sama dengan pembelajaran biasa.

2. Resiliansi matematik siswa secara signifikan antara yang pembelajarannya menggunakan pendekatan problem solving tidak lebih baik atau sama dengan pembelajaran biasa.

3. Tidak terdapat asosiasi antara kemampuan berpikir kritis dengan resiliansi matematik

4. Siswa kelas eksperimen yang pembelajarannya menggunakan pendekatan problem solving maupun siswa kelas kontrol yang pembelajarannya menggunakan pembelajaran biasa mengalami kesulitan dalam menyelesaikan soal nomor 1, 2, dan 5 dengan indikator menyusun jawaban/ menyelesaikan masalah matematika disertai alasan dan memeriksa kebenaran argumen, pernyataan dan proses solusi.

\section{REFERENSI}

Hadinata, B. (2009). Berpikir Kritis Sebuah Pengantar Alec Fisher. Jakarta: Erlangga.

Johnston-Wilder, S. and Lee, C. (2010). Developing Mathematical Resilience. Paper presented at the BERA annual conference at Warwict University.

Karatas, I., dan Baki, A. 2013. The Effect of Learning Environments Based on Problem Solving on Students' Achievements of Problem Solving. In International Electronic Journal of Elementary Education, 5(3), 249-268.

Majid, A. (2013). Strategi Pembelajaran. Bandung: PT Remaja Rosdakarya.

Murni, S. (2017). Meningkatkan Kemampuan Berpikir Kritis dan Kreatif serta Resiliansi Matematik Siswa SMA Negeri di Kota Cimahi Melalui Pendekatan Realistic Mathematics Education. Tesis STKIP Siliwangi. Bandung: Tidak diterbitkan

Perveen, K. 2010. Effect of The Problem-Solving Approach on Academic Achievement of Students in Mathematics at the Secondary Level. Dimuat dalam Contemporary Issues In Education Research, Volume 3 Number 3, 9-13.

Rohaeti, E.E. (2008). Pembelajaran dengan Pendekatan Eksplorasi untuk Mengembangkan Kemampuan Berpikir Kritis dan Kreatif Matematik Siswa Sekolah Menengah Pertama. Disertasi Universitas Pendidikan Indonesia. Bandung: Tidak diterbitkan.

Rohaeti, E. E. (2010). Critical and Creative Mathematical Thinking of Junior High School Students. Dimuat dalam Educationist, Volume IV No. 2 pp 99-106.

Ruseffendi, E.T. (1991). Penilaian Pendidikan dan Hasil Belajar Siswa Khususnya dalam Pengajaran Matematika. Bandung: Tidak diterbitkan.

Ruseffendi, E. T. (2010). Dasar-Dasar Penelitian Pendidikan dan Bidang Non-Eksakta Lainnya. Bandung: Tarsito. 
Susilawati, W. (2014). Belajar dan Pembelajaran Matematika. Bandung: CV. Insan Mandiri.

Widyatiningtyas, R., Kusumah, Y. S., Sumarmo, U., dan Sabandar, J. (2015). The Impact of Problem-Based Learning Approach to Senior High School Students' Mathematics Critical Thinking Ability. Dimuat dalam IndoMS-JME, Volume 6 No. 2 pp 30-38. 